Supporting Information

\title{
Reaction Kinetics of Nitric Oxide on Size-Selected Silver Cluster Cations
}

Masashi Arakawa*, Masataka Horioka, Kento Minamikawa, Tomoki Kawano, and Akira Terasaki*

Department of Chemistry, Faculty of Science, Kyushu University, 744 Motooka, Nishi-ku, Fukuoka 819-0395, Japan

\section{Contents}

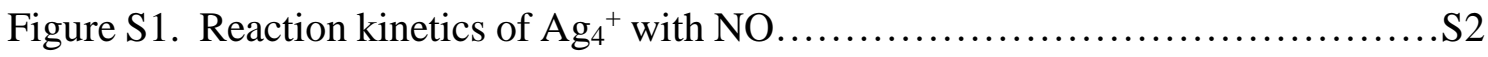

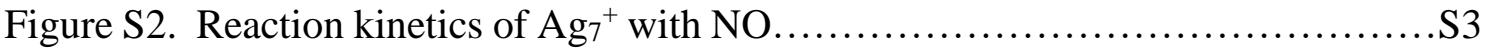

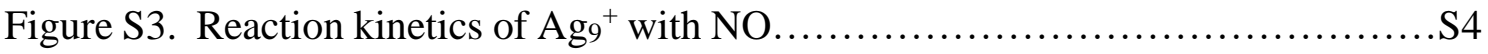

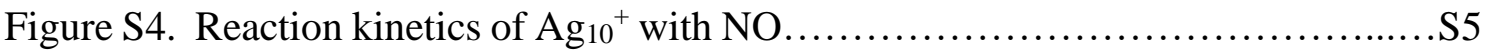

Figure S5. Reaction kinetics of $\mathrm{Ag}_{11}{ }^{+}$with NO................................... 6

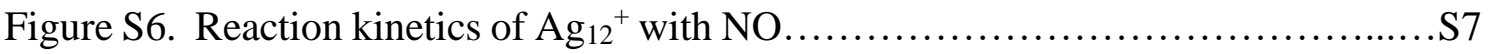



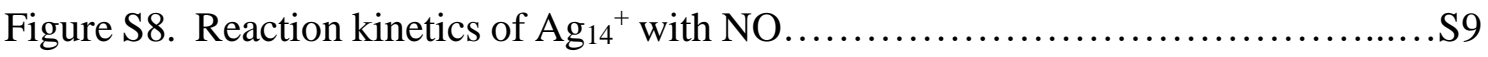





Figure S1. Reaction kinetics of $\mathrm{Ag}_{4}{ }^{+}$with NO. The ion signals of the reactant and products are plotted as a function of storage time; $\mathrm{Ag}_{4}{ }^{+}$(closed circles), $\mathrm{Ag}_{4} \mathrm{O}^{+}$(closed triangles), $\mathrm{Ag}_{4} \mathrm{NO}_{2}{ }^{+}$(closed squares), and $\mathrm{Ag}_{3}{ }^{+}$(open diamonds). The partial pressure of NO was estimated to be about $3 \times 10^{-3} \mathrm{~Pa}$ in the ion trap. Solid lines are fitting curves to pseudo-first-order rate equations based on the reaction pathway shown below each panel. The pseudo-first-order rate constants of each reaction are given above each arrow in $\mathrm{s}^{-1}$. The best fit was obtained for (a); panel (b) does not reproduce, in particular, the behaviors of $\mathrm{Ag}_{4} \mathrm{O}^{+}$and $\mathrm{Ag}_{3}{ }^{+}$. 


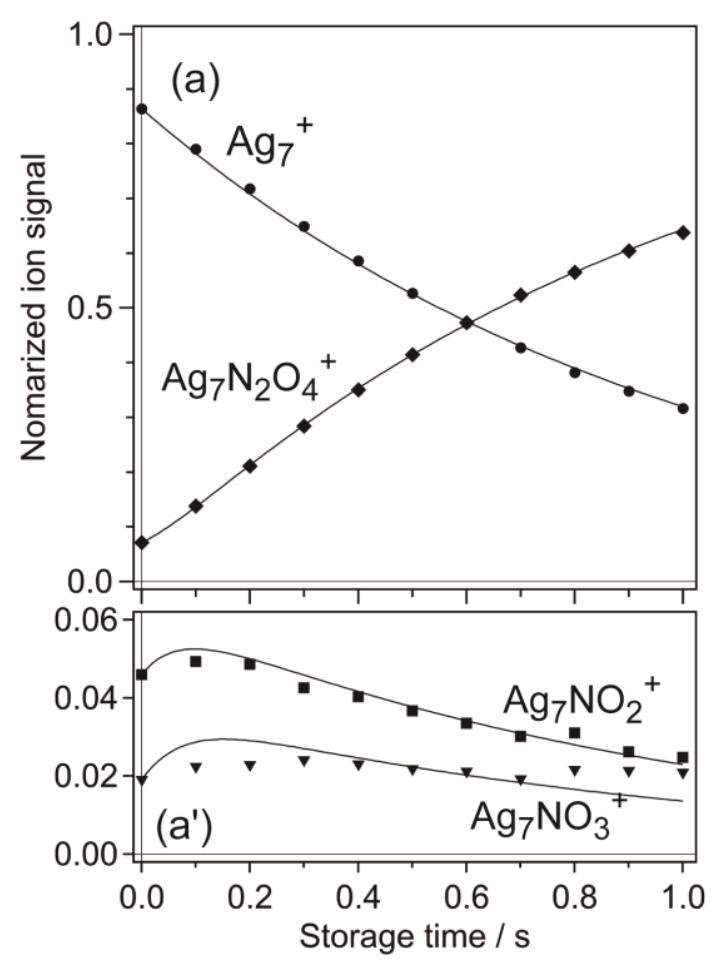

$\mathrm{Ag}_{7} \stackrel{0.99}{\longrightarrow} \mathrm{Ag}_{7} \mathrm{NO}_{2} \stackrel{14.84}{\longrightarrow} \mathrm{Ag}_{7} \mathrm{NO}_{3} \stackrel{26.04}{\longrightarrow} \mathrm{Ag}_{7} \mathrm{~N}_{2} \mathrm{O}_{4}^{+}$

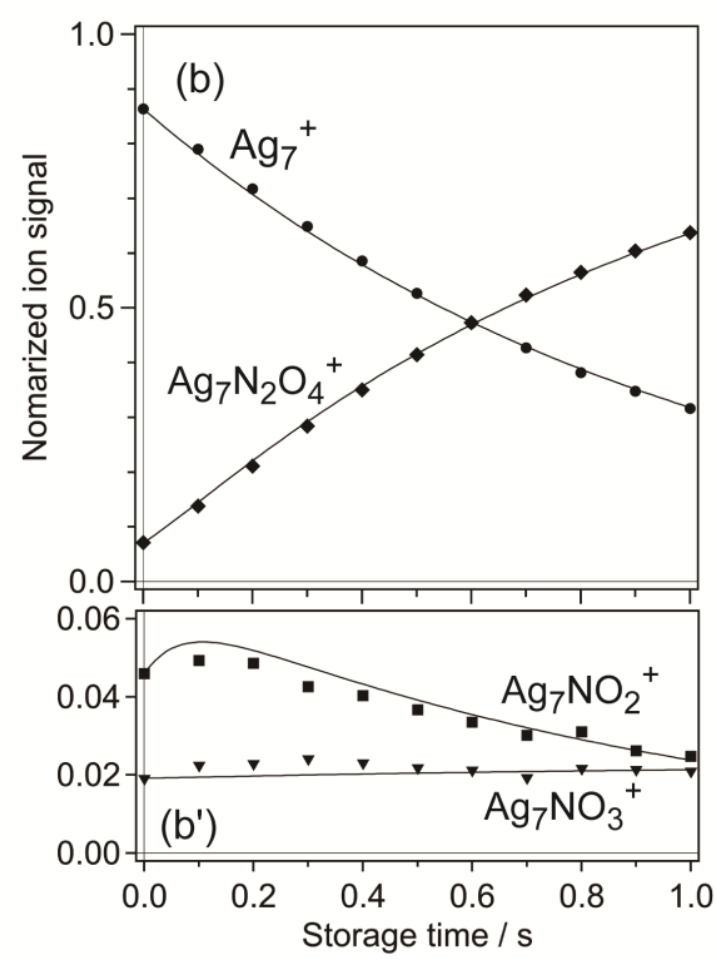

$\mathrm{Ag}_{7}+\stackrel{0.99}{\longrightarrow} \mathrm{Ag}_{7} \mathrm{NO}_{2} \stackrel{0.055}{\longrightarrow} \mathrm{Ag}_{7} \mathrm{NO}_{3}{ }^{+}$
$\stackrel{14.29}{\longrightarrow} \mathrm{Ag}_{7} \mathrm{~N}_{2} \mathrm{O}_{4}^{+}$

Figure S2. Reaction kinetics of $\mathrm{Ag}_{7}{ }^{+}$with NO. Minor products are displayed in a magnified scale in $\left(a^{\prime}\right)$ and $\left(b^{\prime}\right)$. The ion signals of the reactant and products are plotted as a function of storage time; $\mathrm{Ag}_{7}{ }^{+}$(closed circles), $\mathrm{Ag}_{7} \mathrm{NO}_{2}{ }^{+}$(closed squares), $\mathrm{Ag}_{7} \mathrm{NO}_{3}{ }^{+}$ (closed inversed triangles), and $\mathrm{Ag}_{7} \mathrm{~N}_{2} \mathrm{O}_{4}{ }^{+}$(closed diamonds). The partial pressure of NO was estimated to be about $6 \times 10^{-3} \mathrm{~Pa}$ in the ion trap. Solid lines are fitting curves to pseudo-first-order rate equations based on the reaction pathway shown below each panel. The pseudo-first-order rate constants of each reaction are given above each arrow in $\mathrm{s}^{-1}$. Panel ( $b$ and $b^{\prime}$ ) gives better fits, in particular, for $\mathrm{Ag}_{7} \mathrm{NO}_{3}{ }^{+}$. 

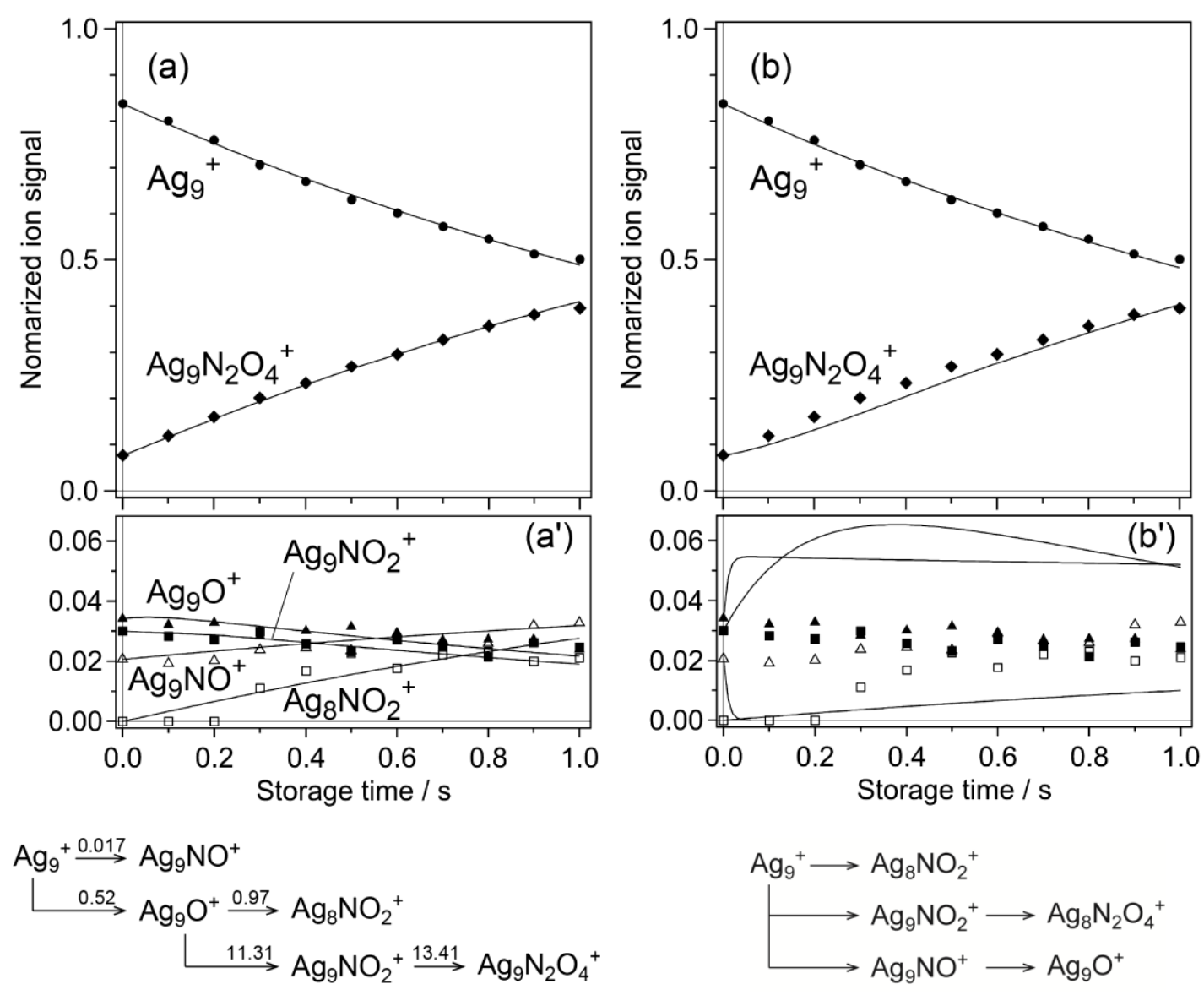

Figure S3. Reaction kinetics of $\mathrm{Ag}_{9}{ }^{+}$with NO. Minor products are displayed in a magnified scale in $\left(a^{\prime}\right)$. The ion signals of the reactant and products are plotted as a function of storage time; $\mathrm{Ag}_{9}{ }^{+}$(closed circles), $\mathrm{Ag}_{9} \mathrm{O}^{+}$(closede triangles), $\mathrm{Ag}_{9} \mathrm{NO}_{2}{ }^{+}$ (closed squares), $\mathrm{Ag}_{9} \mathrm{~N}_{2} \mathrm{O}_{4}{ }^{+}$(closed diamonds), $\mathrm{Ag}_{9} \mathrm{NO}^{+}$(open traiangles), $\mathrm{Ag}_{8} \mathrm{NO}_{2}{ }^{+}$ (open squares). The partial pressure of $\mathrm{NO}$ was estimated to be about $3 \times 10^{-2} \mathrm{~Pa}$ in the ion trap. Solid lines are fitting curves to pseudo-first-order rate equations based on the reaction pathway shown below the panel. The pseudo-first-order rate constants of each reaction are given above each arrow in $\mathrm{s}^{-1}$. The best fit was obtained for (a); panel (b) does not at all reproduce the behaviors of product ions, where reasonable rate constants were not obtained. 

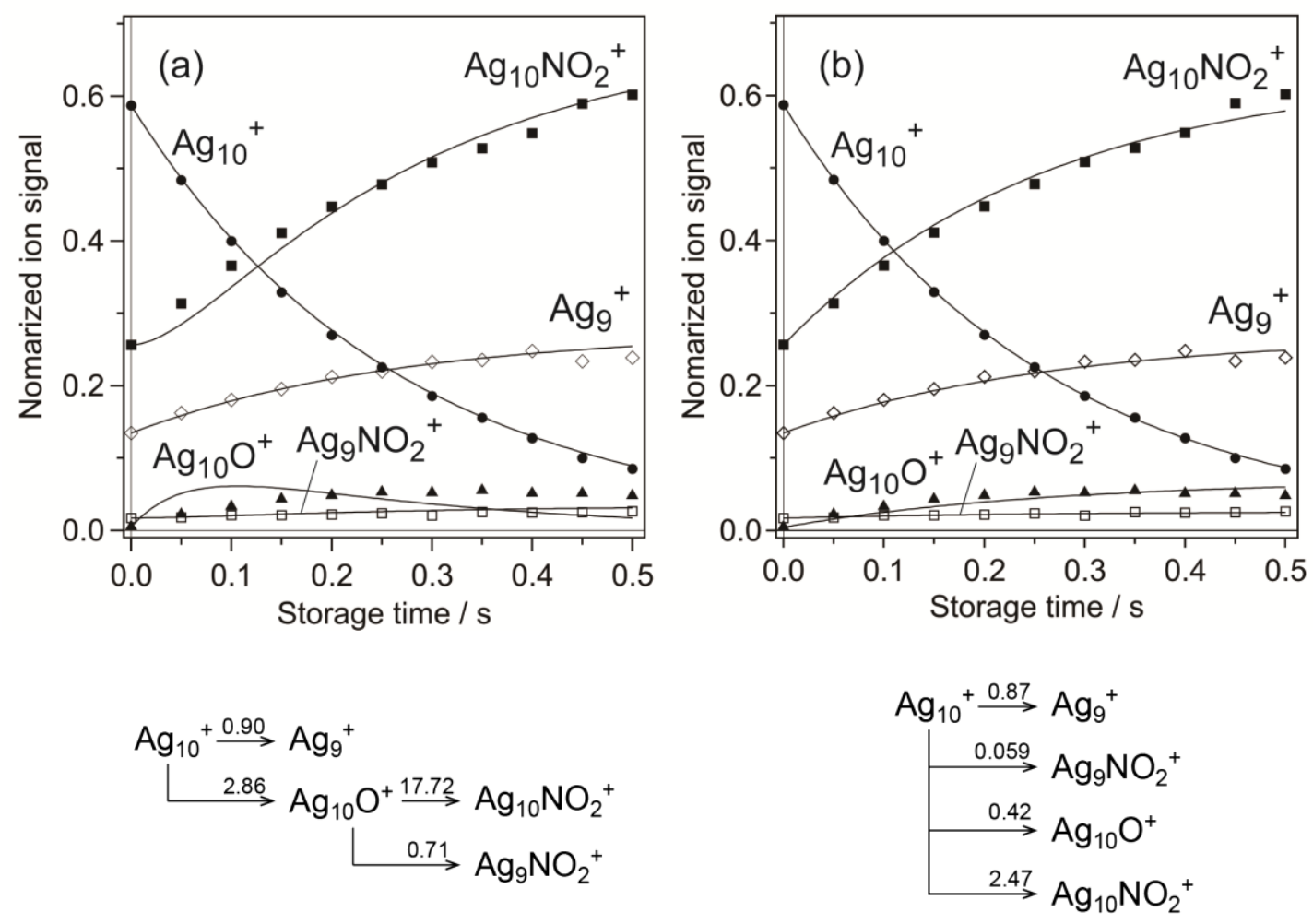

Figure S4. Reaction kinetics of $\mathrm{Ag}_{10}{ }^{+}$with NO. The ion signals of the reactant and products are plotted as a function of storage time; $\mathrm{Ag}_{10}{ }^{+}$(closed circles), $\mathrm{Ag}_{10} \mathrm{O}^{+}$(closed triangles), $\mathrm{Ag}_{10} \mathrm{NO}_{2}{ }^{+}$(closed squares), $\mathrm{Ag}_{9}{ }^{+}$(open diamonds), and $\mathrm{Ag}_{9} \mathrm{NO}_{2}{ }^{+}$(open squares). The partial pressure of NO was estimated to be about $3 \times 10^{-3} \mathrm{~Pa}$ in the ion trap. Solid lines are fitting curves to pseudo-first-order rate equations based on the reaction pathway shown below each panel. The pseudo-first-order rate constants of each reaction are given above each arrow in $\mathrm{s}^{-1}$. The best fit was obtained for (b); panel (a) does not reproduce, in particular, the behaviors of $\mathrm{Ag}_{10} \mathrm{O}^{+}$and $\mathrm{Ag}_{10} \mathrm{NO}_{2}{ }^{+}$. 



$$
\begin{aligned}
\mathrm{Ag}_{11} & \stackrel{+2.46}{\longrightarrow} \mathrm{Ag}_{11} \mathrm{O}^{+} \stackrel{16.61}{\longrightarrow} \mathrm{Ag}_{11} \mathrm{NO}_{2}{ }^{+} \longrightarrow \\
& \stackrel{4.70}{\longrightarrow} \mathrm{Ag}_{11} \mathrm{NO}_{3}+\stackrel{11.57}{\longrightarrow} \mathrm{Ag}_{11} \mathrm{~N}_{2} \mathrm{O}_{4}^{+}
\end{aligned}
$$

$$
\begin{aligned}
& \mathrm{Ag}_{11}+\stackrel{0.34}{\longrightarrow} \mathrm{Ag}_{11} \mathrm{O}^{+} \stackrel{+.58}{\longrightarrow} \mathrm{Ag}_{11} \mathrm{NO}_{3}{ }^{+} \\
& \stackrel{2.16}{\longrightarrow} \mathrm{Ag}_{4} \mathrm{NO}_{2}+\stackrel{3.95}{\longrightarrow} \mathrm{Ag}_{11} \mathrm{~N}_{2} \mathrm{O}_{4}{ }^{+}
\end{aligned}
$$

Figure S5. Reaction kinetics of $\mathrm{Ag}_{11}{ }^{+}$with NO. The ion signals of the reactant and products are plotted as a function of storage time; $\mathrm{Ag}_{11}{ }^{+}$(closed circles), $\mathrm{Ag}_{11} \mathrm{O}^{+}$(closed triangles), $\mathrm{Ag}_{11} \mathrm{NO}_{2}{ }^{+}$(closed squares), $\mathrm{Ag}_{11} \mathrm{NO}_{2}{ }^{+}$(closed inversed squares), $\mathrm{Ag}_{11} \mathrm{~N}_{2} \mathrm{O}_{4}{ }^{+}$ (closed diamonds). The partial pressure of $\mathrm{NO}$ was estimated to be about $3 \times 10^{-3} \mathrm{~Pa}$ in the ion trap. Solid lines are fitting curves to pseudo-first-order rate equations based on the reaction pathway shown below each panel. The pseudo-first-order rate constants of each reaction are given above each arrow in $\mathrm{s}^{-1}$. The best fit was obtained for (b); panel (a) does not well reproduce the behaviors of $\mathrm{Ag}_{11} \mathrm{O}^{+}$and $\mathrm{Ag}_{11} \mathrm{NO}_{2}{ }^{+}$. 

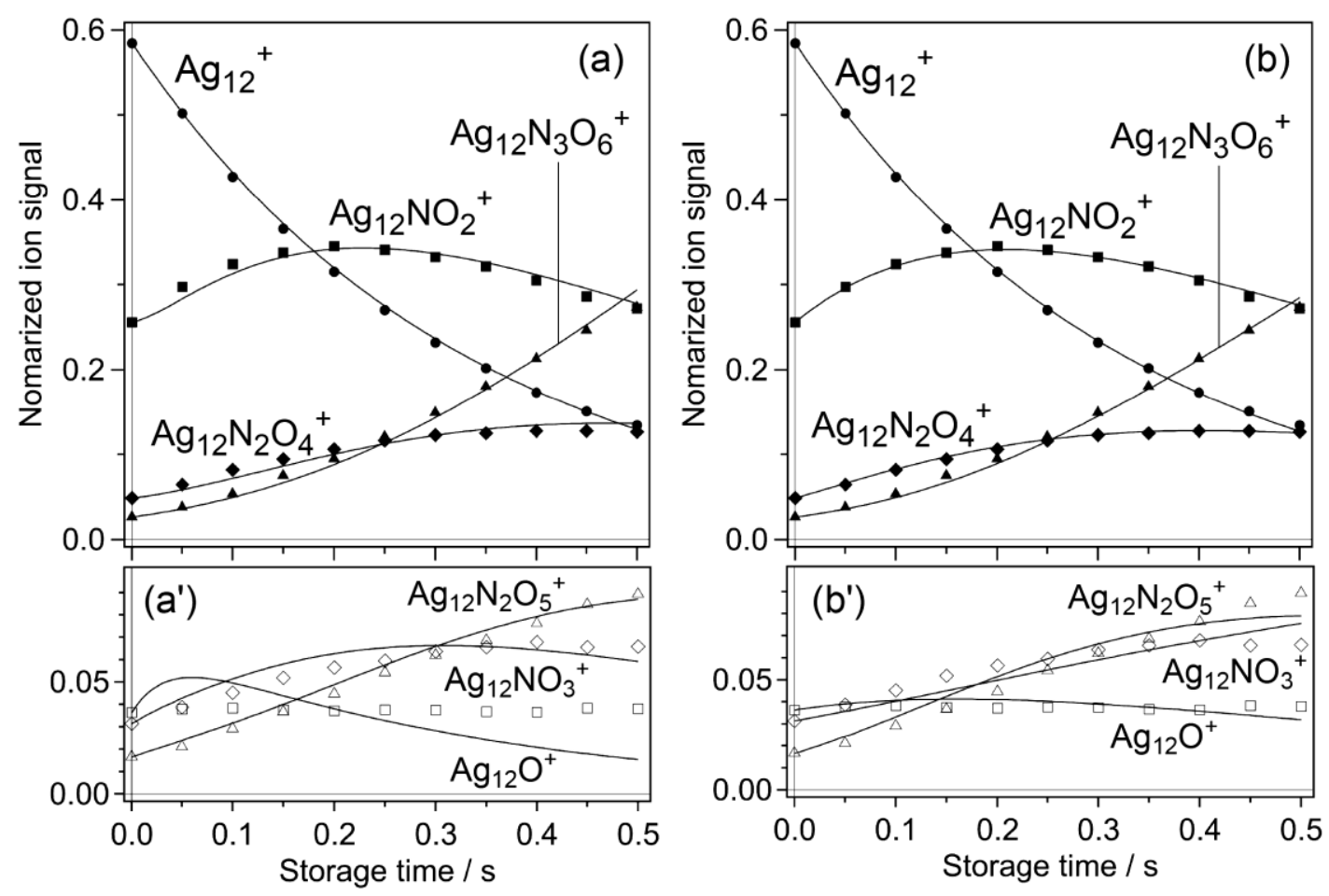

$$
\begin{aligned}
\mathrm{Ag}_{12} & \stackrel{+3.01}{\longrightarrow} \mathrm{Ag}_{12} \mathrm{O}^{+} \stackrel{28.30}{\longrightarrow} \mathrm{Ag}_{12} \mathrm{NO}_{2}^{+} \longrightarrow \\
& \stackrel{2.88}{\longrightarrow} \mathrm{Ag}_{12} \mathrm{NO}_{3} \stackrel{+14.55}{\longrightarrow} \mathrm{Ag}_{12} \mathrm{~N}_{2} \mathrm{O}_{4}^{+} \\
& \stackrel{6.46}{\longrightarrow} \mathrm{Ag}_{12} \mathrm{~N}_{2} \mathrm{O}_{5} \stackrel{\text { +9.61 }}{\longrightarrow} \mathrm{Ag}_{12} \mathrm{~N}_{3} \mathrm{O}_{6}^{+}
\end{aligned}
$$

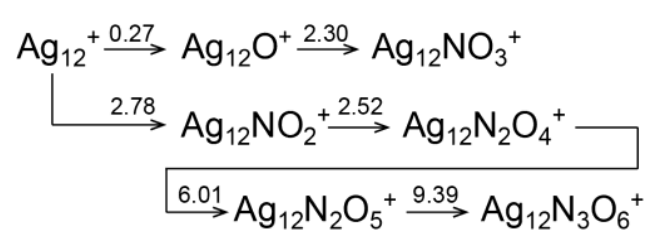

Figure S6. Reaction kinetics of $\mathrm{Ag}_{12}{ }^{+}$with NO. Minor products are displayed in a magnified scale in $\left(a^{\prime}\right)$ and $\left(b^{\prime}\right)$. The ion signals of the reactant and products are plotted as a function of storage time; $\mathrm{Ag}_{12}{ }^{+}$(closed circles), $\mathrm{Ag}_{12} \mathrm{O}^{+}$(open squares), $\mathrm{Ag}_{12} \mathrm{NO}_{2}{ }^{+}$ (closed squares), $\mathrm{Ag}_{12} \mathrm{NO}_{3}{ }^{+}$(open diamonds), $\mathrm{Ag}_{12} \mathrm{~N}_{2} \mathrm{O}_{4}{ }^{+}$(closed diamonds), $\mathrm{Ag}_{12} \mathrm{~N}_{2} \mathrm{O}_{5}{ }^{+}$ (open triangles), and $\mathrm{Ag}_{12} \mathrm{~N}_{3} \mathrm{O}_{6}{ }^{+}$(closed triangles). The partial pressure of $\mathrm{NO}$ was estimated to be about $3 \times 10^{-3} \mathrm{~Pa}$ in the ion trap. Solid lines are fitting curves to pseudofirst-order rate equations based on the reaction pathway shown below each panel. The pseudo-first-order rate constants of each reaction are given above each arrow in $\mathrm{s}^{-1}$. The best fit was obtained for (b). 

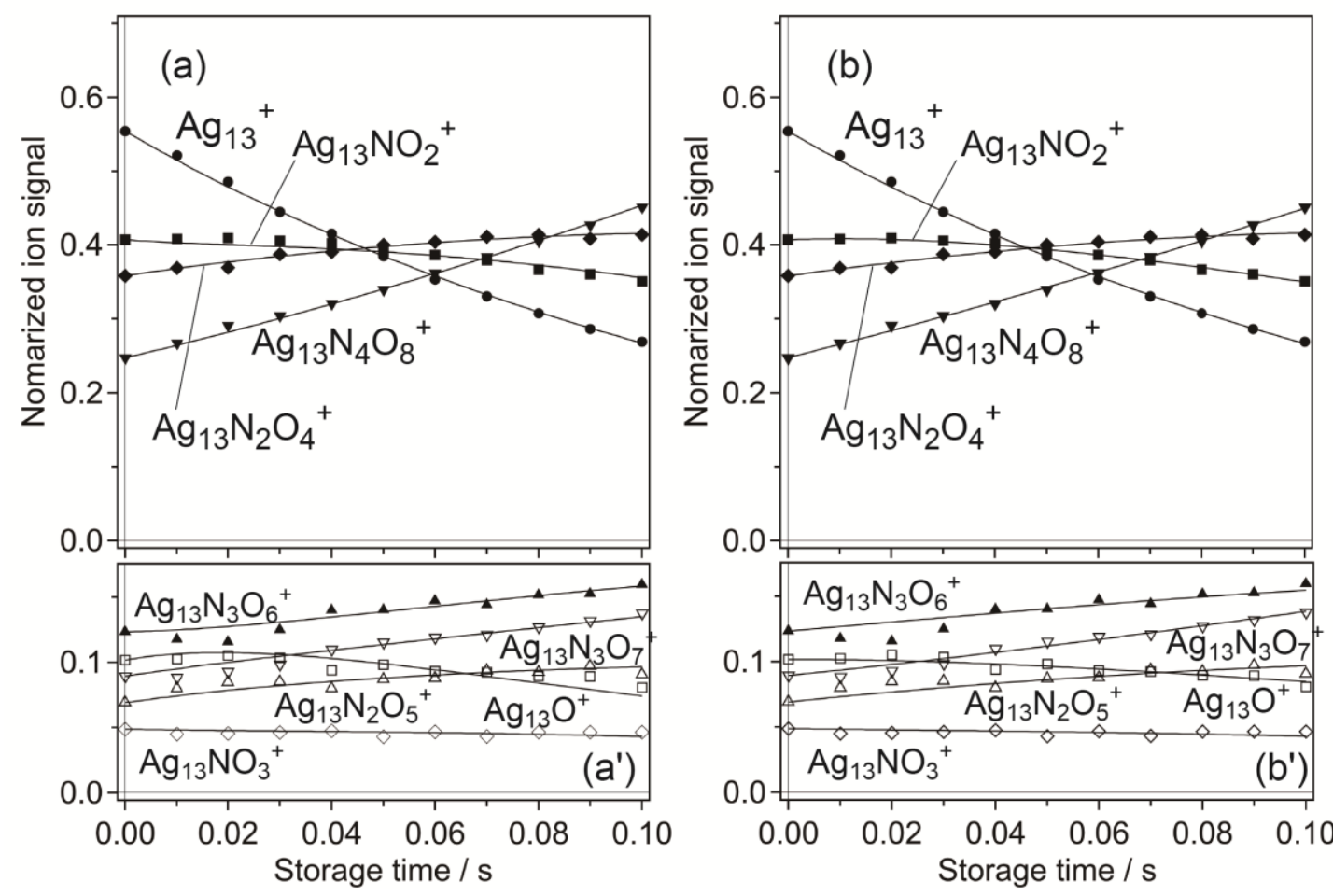

$$
\begin{aligned}
\mathrm{Ag}_{13} & \stackrel{+}{\stackrel{7.30}{\longrightarrow}} \mathrm{Ag}_{13} \mathrm{O}^{+} \stackrel{32.8}{\longrightarrow} \mathrm{Ag}_{13} \mathrm{NO}_{2}{ }^{+} \longrightarrow \\
& \stackrel{9.46}{\longrightarrow} \mathrm{Ag}_{13} \mathrm{NO}_{3} \stackrel{+80.16}{\longrightarrow} \mathrm{Ag}_{13} \mathrm{~N}_{2} \mathrm{O}_{4}{ }^{+} \\
& \stackrel{7.97}{\longrightarrow} \mathrm{Ag}_{13} \mathrm{~N}_{2} \mathrm{O}_{5} \stackrel{\text { 33.18 }}{\longrightarrow} \mathrm{Ag}_{13} \mathrm{~N}_{3} \mathrm{O}_{6}{ }^{+} \\
& \stackrel{18.65}{\longrightarrow} \mathrm{Ag}_{13} \mathrm{~N}_{3} \mathrm{O}_{7} \stackrel{18.18}{\longrightarrow} \mathrm{Ag}_{13} \mathrm{~N}_{4} \mathrm{O}_{8}^{+}
\end{aligned}
$$

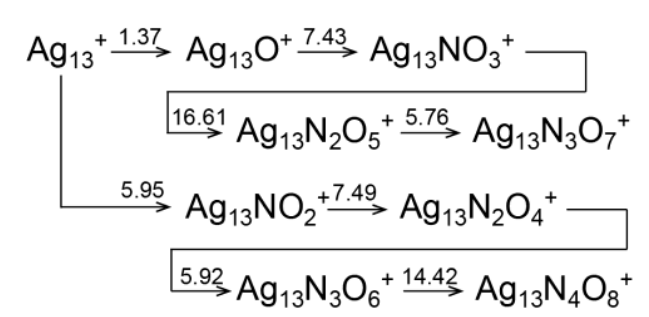

Figure S7. Reaction kinetics of $\mathrm{Ag}_{13}{ }^{+}$with NO. Minor products are displayed in a magnified scale in $\left(a^{\prime}\right)$ and $\left(b^{\prime}\right)$. The ion signals of the reactant and products are plotted as a function of storage time; $\mathrm{Ag}_{13}{ }^{+}$(closed circles), $\mathrm{Ag}_{13} \mathrm{O}^{+}$(open squares), and $\mathrm{Ag}_{13} \mathrm{NO}_{2}{ }^{+}$(closed squares), $\mathrm{Ag}_{13} \mathrm{NO}_{3}{ }^{+}$(open diamonds), $\mathrm{Ag}_{13} \mathrm{~N}_{2} \mathrm{O}_{4}{ }^{+}$(closed diamonds), $\mathrm{Ag}_{13} \mathrm{~N}_{2} \mathrm{O}_{5}{ }^{+}$(open triangles) $\mathrm{Ag}_{13} \mathrm{~N}_{3} \mathrm{O}_{6}{ }^{+}$(closed triangles), $\mathrm{Ag}_{13} \mathrm{~N}_{3} \mathrm{O}_{7}{ }^{+}$(open inversed triangles), and $\mathrm{Ag}_{13} \mathrm{~N}_{4} \mathrm{O}_{8}{ }^{+}$(closed inversed triangles). The partial pressure of NO was estimated to be about $1 \times 10^{-2} \mathrm{~Pa}$ in the ion trap. Solid lines are fitting curves to pseudofirst-order rate equations based on the reaction pathway shown below each panel. The pseudo-first-order rate constants of each reaction are given above each arrow in s ${ }^{-1}$. Both (a) and (b) reproduce the kinetics equally well. 

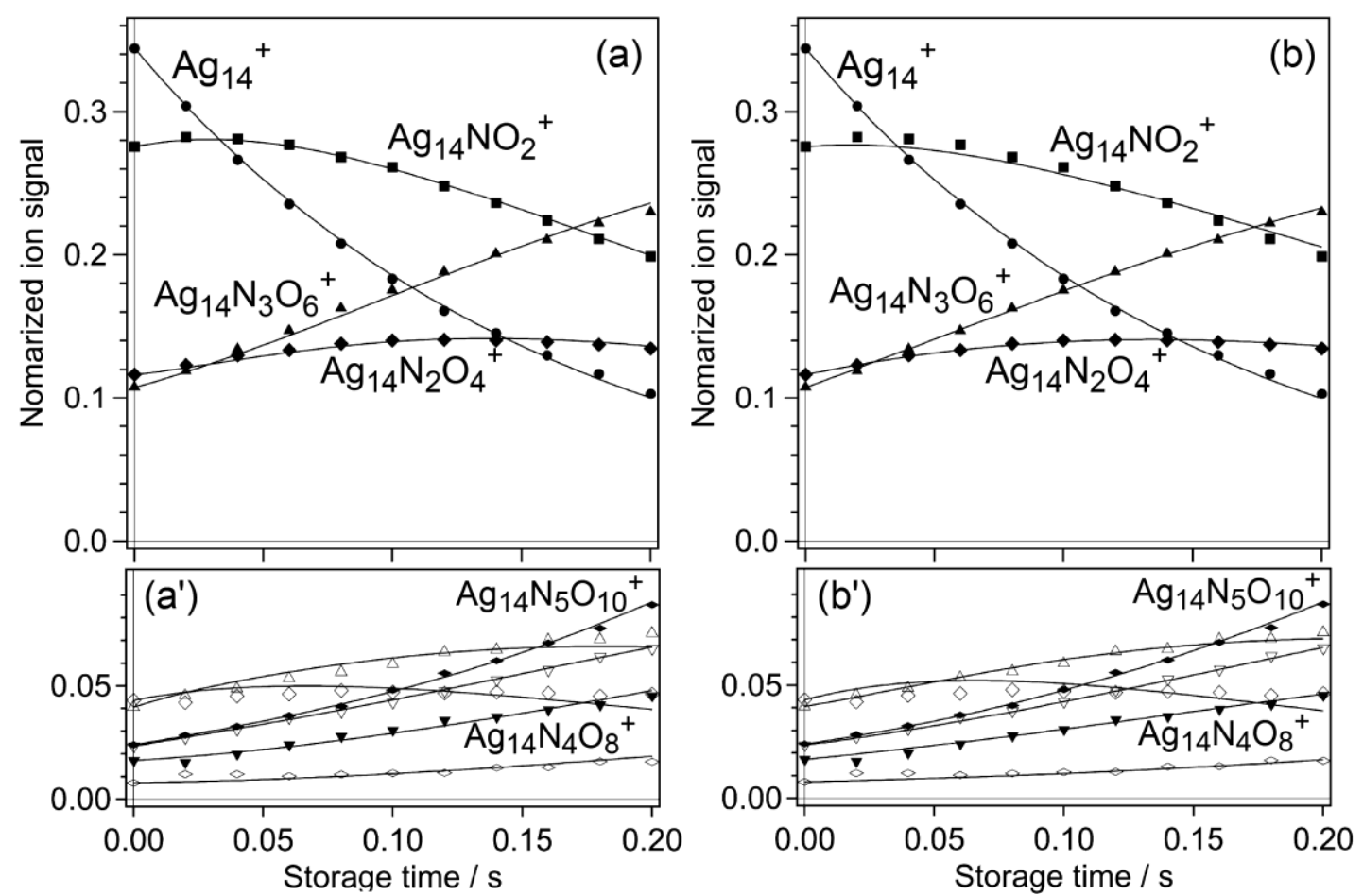

$$
\begin{aligned}
\mathrm{Ag}_{14} & \stackrel{6.17}{\longrightarrow} \mathrm{Ag}_{14} \mathrm{NO}_{2} \stackrel{+6.33}{\rightarrow} \mathrm{Ag}_{14} \mathrm{NO}_{3}{ }^{+} \\
& \stackrel{34.71}{\longrightarrow} \mathrm{Ag}_{14} \mathrm{~N}_{2} \mathrm{O}_{4} \stackrel{+11.31}{\longrightarrow} \mathrm{Ag}_{14} \mathrm{~N}_{2} \mathrm{O}_{5}{ }^{+} \\
& \stackrel{23.25}{\longrightarrow} \mathrm{Ag}_{14} \mathrm{~N}_{3} \mathrm{O}_{6}+\stackrel{4.35}{\longrightarrow} \mathrm{Ag}_{14} \mathrm{~N}_{3} \mathrm{O}_{7}^{+} \\
& \stackrel{11.90}{\longrightarrow} \mathrm{Ag}_{14} \mathrm{~N}_{4} \mathrm{O}_{8}+\stackrel{12.36}{\longrightarrow} \mathrm{Ag}_{14} \mathrm{~N}_{4} \mathrm{O}_{9}^{+} \\
& \stackrel{26.45}{\longrightarrow} \mathrm{Ag}_{14} \mathrm{~N}_{5} \mathrm{O}_{10}+
\end{aligned}
$$

$$
\begin{aligned}
& \mathrm{Ag}_{14} \stackrel{1.98}{\longrightarrow} \mathrm{Ag}_{14} \mathrm{NO}_{3} \stackrel{+8.67}{\longrightarrow} \mathrm{Ag}_{14} \mathrm{~N}_{2} \mathrm{O}_{5}{ }^{+} \\
& \stackrel{4.47}{\longrightarrow} \mathrm{Ag}_{14} \mathrm{~N}_{3} \mathrm{O}_{7}+\stackrel{1.12}{\longrightarrow} \mathrm{Ag}_{14} \mathrm{~N}_{4} \mathrm{O}_{9}^{+} \\
& 4.22 \\
& \mathrm{Ag}_{14} \mathrm{NO}_{2} \stackrel{+.71}{\longrightarrow} \mathrm{Ag}_{14} \mathrm{~N}_{2} \mathrm{O}_{4}{ }^{+} \\
& \stackrel{8.03}{\longrightarrow} \mathrm{Ag}_{14} \mathrm{~N}_{3} \mathrm{O}_{6} \stackrel{2.65}{\longrightarrow} \mathrm{Ag}_{14} \mathrm{~N}_{4} \mathrm{O}_{8}{ }^{+} \\
& \stackrel{10.11}{\longrightarrow} \mathrm{Ag}_{14} \mathrm{~N}_{5} \mathrm{O}_{10}{ }^{+}
\end{aligned}
$$

Figure S8. Reaction kinetics of $\mathrm{Ag}_{14}{ }^{+}$with NO. Minor products are displayed in a magnified scale in $\left(a^{\prime}\right)$ and $\left(b^{\prime}\right)$. The ion signals of the reactant and products are plotted as a function of storage time; $\mathrm{Ag}_{14}{ }^{+}$(closed circles), $\mathrm{Ag}_{14} \mathrm{NO}_{2}{ }^{+}$(closed squares), $\mathrm{Ag}_{14} \mathrm{NO}_{3}{ }^{+}$(open diamonds), $\mathrm{Ag}_{14} \mathrm{~N}_{2} \mathrm{O}_{4}{ }^{+}$(closed diamonds), $\mathrm{Ag}_{14} \mathrm{~N}_{2} \mathrm{O}_{5}{ }^{+}$(open triangles) $\mathrm{Ag}_{14} \mathrm{~N}_{3} \mathrm{O}_{6}{ }^{+}$(closed triangles), $\mathrm{Ag}_{14} \mathrm{~N}_{3} \mathrm{O}_{7}{ }^{+}$(open inversed triangles), $\mathrm{Ag}_{14} \mathrm{~N}_{4} \mathrm{O}_{8}{ }^{+}$(closed inversed triangles), $\mathrm{Ag}_{14} \mathrm{~N}_{4} \mathrm{O}_{9}{ }^{+}$(open rhombus), and $\mathrm{Ag}_{14} \mathrm{~N}_{5} \mathrm{O}_{10}{ }^{+}$(closed rhombus). The partial pressure of NO was estimated to be about $9 \times 10^{-3} \mathrm{~Pa}$ in the ion trap. Solid lines are fitting curves to pseudo-first-order rate equations based on the reaction pathway shown below each panel. The pseudo-first-order rate constants of each reaction are given above each arrow in $\mathrm{s}^{-1}$. Both (a) and (b) reproduce the kinetics equally well. 